BERTEL NYGAARD

Ph.d., lektor ved Institut for Kultur og Samfund, Aarhus Universitet

\title{
KARL MARX OG FORTIDENS UTOPISKE POTENTIALER
}

\begin{abstract}
KARL MARX AND THE UTOPIAN POTENTIALS OF THE PAST ｜Ｋarl Marx explicitly situated modern emancipation struggles in the present rejecting the power of the past over the present along with utopian schemes for the future. But a closer study of his position reveals that his notion of the present was remarkably open towards aspects of the past and potentials for future alternatives, as long as these were conceived from - and as moments within - present struggles. Thus, his rejection of certain visions of past and future was mainly a critique of specific ideological configurations characteristic of modern bourgeois society, including reified notions of the past, history and temporality. From

this critique we may derive a fruitful, discerning approach to the complex interrelations of utopia, ideology, past, present and future, founded on a critical reconstruction of the category of time as a differential social relation, persistently constructed and reconstructed through conflictual social agency.
\end{abstract}

KEYWORDS I utopia, history, ideology, time, Karl Marx.

"Det nittende århundredes sociale revolution kan ikke hente sin poesi fra fortiden, men kun fra fremtiden. Den kan ikke begynde med sig selv, før den har rystet al overtro på fortiden af sig. De tidligere revolutioner trængte til de verdenshistoriske minder om fortiden for at bedøve sig selv over for deres eget indhold. Det nittende århundredes revolution må lade de døde begrave deres døde for at finde frem til sit eget indhold. Dengang gik ordene videre end indholdet, nu går indholdet videre end ordene". (Marx, "Brumaire" II7)

Revolutionens "eget indhold" lå i nuet. Fortidsminderne måtte begraves. Man måtte bryde traditionens magt, der hvilede "som en mare på de levendes hjerner". Dette understregede Karl Marx i skriftet Der achtzehnte Brumaire des Louis Bonaparte (Louis Bonapartes attende Brumaire) fra I852 (Marx, "Brumaire" II5). På omtrent IOO sider gjorde han her status over nederlaget for den franske del af den store europæiske revolutionsbølge i I848: nedlæggelsen af den kortvarige anden republik og oprettelsen af det andet imperium under Louis Bonaparte - nevø af den første Napoleon. Hans fortidskritik var rettet mod de revolutionære, der havde anset sig selv for blotte reinkarnationer af helteskikkelser i blotte repetitioner af forgangne, sejrrige revolutioner.

Uddrivelsen af fortidens genfærd forbandt sig tæt med Marx' kritik af utopiske fremtidsspekulationer. Nok pegede han her mod en endnu ikke eksisterende - og

4 INDHOLD

DETTE MATERIALE ER OPHAVSRETSLIGT BESKYTTET OG MÅ IKKE VIDEREGIVES 
i den forstand utopisk - kommunistisk fremtid som kilde til revolutionens 'poesi'. Kommunismen var imidlertid ikke "en tilstand, der skal skabes, et ideal, hvorefter virkeligheden haver at rette sig", men derimod "den virkelige bevægelse, der ophæver den nuværende tilstand". Og denne bevægelses rette erkendelsesform var den nøgterne, videnskabelige analyse af det eksisterende - ikke drømmerejsens luftige visioner (Marx og Engels, "Die deutsche" 25; jf. hertil Maler; Abensour; Bloch, Prinzip 288-334; Geoghegan 39-54; Levitas 35-58). Både fortidsdyrkelsen og den spekulative fremtidsutopisme truede med at aflede emancipationsbestræbelserne fra nutidens påtrængende kampe og erkendelsesbehov. Disse afledninger fra nutiden betød samtidig, at disse bestræbelser blev indordnet under foruddefinerede endemål (fortidens determinationer eller det enkelte utopiudkastende subjekts vilje), der uvægerligt måtte være ideologisk betinget af deres historiske ophav i de endnu ufrie samfund (Marin). Arbejderklassens frigørelse måtte for Marx ikke tage form af "opskrifter ... for fremtidens spisehuse", men "erobres af arbejderklassen selv" gennem dens "historisk[e] selvaktivitet" (Marx, "Nachwort" 25; Marx, "Provisorische" I4; Marx og Engels, "Manifest" 490). For Marx kunne fremtidssamfundet således kun blive virkelig frit, hvis det blev konstrueret gennem de aktuelt undertryktes egen befrielseskamp - i nuet.

På den baggrund kan det synes som en dobbelt besynderlighed at gå til Marx' skrifter for ikke alene at søge det utopiske, men også gøre det gennem hans karakteristikker af fortiden. Ikke desto mindre vil jeg i denne artikel fremdrage netop utopiske potentialer i fortiden gennem en nærmere analyse af Brumaire-teksten som både en kontekstbestemt politisk intervention og en tekst med teoretisk-metodiske implikationer i selve sine politisk historiebrugende handlinger.

En gennemgående tese vil være, at Marx i Brumaire-teksten udfoldede en grundlæggende opfattelse af historisk tid som en differentiel social relation under stadig konstruktion med udgangspunkt i et åbent, modsætningsfyldt $n u$. Dette satte ham i stand til at distancere sig fra både udfoldede utopiske visioner, utopisme og nostalgisk fortidsdyrkelse, men samtidig åbne sit perspektiv for det, Ernst Bloch kaldte for utopiske funktioner $\mathrm{i}$ både de fortrængte fortidslevn og endnu uindløste fremtidspotentialer, der trænger sig på i menneskets samfundsmæssige nutidseksistens. For Marx var sådanne utopiske funktioner, med Fredric Jamesons nutidige formulering, på én gang udtryk for og udøvelse af sprækker og differens inden for nutiden (Jameson I5; jf. også Ollman, Dance I55-I69).

\section{Universalteori eller politisk handling?}

En udlægning af "historiens store store bevægelseslov", kaldte Friedrich Engels Brumaire-teksten, da han lod den genudgive i i885, to år efter Marx' død (Engels, "Vorrede" 248). Denne genudgivelse sikrede teksten en plads i den tekstkanon, der skulle udgøre fundamentet for marxismen som en systematisk, altomfattende verdensanskuelse - et modbillede til samtidens positivistisk dominerede, borgerlige videnskab (Anderson 6; Hobsbawm I76-196). Kanoniseringen betød ikke mindst, 
at Marx' og Engels' meget forskelligartede, ofte tidsbundne skrifter for eftertiden kom til at fremstå som et arsenal af færdige teoretiske bestemmelser, der syntes at gøre fordring på umiddelbar, almen gyldighed inden for det felt, de adresserede.

Men læser vi videre i Marx' og Engels' egne tekster, kan vi måske trænge ind til andre forståelser. I Brumaire-teksten behøver vi blot at bladre et par sider fra Engels' senere forord til de øvrige tekstoplysninger, for at et ganske andet billede af teksten begynder at tegne sig. Teksten blev oprindelig publiceret som artikelserie i Joseph Weydemeyers månedsskrift Die Revolution i 1852, dvs. kun få uger og måneder efter de begivenheder, den beskrev. Sytten år senere udkom teksten for første gang $i$ bogform. I forordet til denne udgivelse understregede Marx, at skriftet var opstået "under umiddelbart indtryk af begivenhederne", og at genudgivelsen i bogform ikke skete på hans eget initiativ, men på andres opfordring (Marx, "Vorwort" 358).

Betød det, at han ikke længere stod inde for indholdet, og at han ikke tilkendte det almen teoretisk værdi? Politologen James Martins læsning af Brumaire-teksten fra 2002 synes at antage det ved at lægge afstand til den traditionelle, kontekstløse forståelse for i stedet at fremhæve teksten som et strengt situationsbundet politisk debatindlæg. Jeg vil derimod i det følgende tage udgangspunkt i den antagelse, at her gemmer sig en åbning ind til en forståelse af Marx’ samfundstænkning som på én gang historisk-praktisk og teoretisk-almen.

Som filosoffen Daniel Bensaid har bemærket, kan man i Marx' mere konjunkturbundne, samtidshistoriske skrifter - som f.eks. Brumaire-teksten - se "eksempler på en historisk kundskab i dens tilblivelse". Her er kortlægninger af et historisk nu, der ikke er "et led i nogen mekanisk sekvens af virkninger og årsager, men en samtidighed fuld af muligheder, hvori politikken får forrang frem for historien $\mathrm{i}$ dechifreringen af tendenser, der ikke har kraft af love" - en samtidighed af usamtidige elementer, der nærer den politiske handling som en radikal rekonfiguration af rammerne om det mulige (Bensaïd I3f, jf. 22). Politikken ses således som en form for nybrydende handling, der ikke opererer på trods af de forudgående betingelser eller på grundlag af dem, men også selv bidrager til at frembringe og forme sine egne mulighedsbetingelser.

Denne form for kontekstuelt formet, politisk-praktisk båret erkendelse kan udfoldes gennem en nærmere analyse af tidslag i Brumaire-teksten.

\section{Illusionernes nødvendighed og utopien i nuet}

I højere grad end sin umiddelbare forgænger, artikelserien Klassekampene $i$ Frankrig I848/50 fra I850, er Der achtzehnte Brumaire des Louis Bonaparte fuld af satiriske og polemiske elementer. Her er nådesløse skildringer af personer, politiske partier og de klasser, hvis passivitet, magtesløshed eller reaktionære tilbøjeligheder banede vej for denne revolutions endelige nederlag.

Afvisningen af "fortidens poesi" er et gennemgående element i tekstens kritik af utallige former for overtro og illusioner. Her er tilbagevendende satiriske referencer til anakronismer: det gamle Ægypten, det gamle Rom, oldgræsk mytologi, Aleksan- 
der den Store, Henrik den Femte, "sabelens og præstekjolens skamløst enkle herredømme", den autoritære statsmagt som et "damoklessværd" over bourgeoisiets eget hoved (Marx, "Brumaire" II8 \& I54). Alle disse fortidsreferencer har dog specifikke adressater i den nyere historie: De borgerlige revolutionære i I848-49 hyldede sig i illusioner om at gentage fortidige heroiske forløb, især dem fra I789-revolutionen. Disse tidligere, betydeligere hændelser - med Marx' ofte citerede ord fra denne tekst: de tragedier, der gik forud for de nylige farcer - havde også selv været næret af forestillinger om fjernere fortider: den romerske republik i I789, gammeltestamentlig tid i Cromwell-tidens England halvandet århundrede før (Marx, "Brumaire" II5). I alle disse tilfælde var ordene gået hinsides indholdet, som Marx formulerede det. Menneskenes "forestillinger" om sig selv og deres livsbetingelser svarede ikke til deres "realitet" (Marx, "Brumaire" I39).

Adskillelsen af ord og indhold kan ved første øjekast synes at bekræfte konventionelle opfattelser af Marx' stræben efter at reducere overbygningens ideologiske former til en almægtig økonomisk-materiel basis. Men Marx hævdede ikke at udlede menneskenes bevidsthedsformer af 'økonomien' som distinkt sfære, men derimod af deres "sociale eksistensbetingelser", deres "samfundsmæssige væren" (Marx, "Brumaire" I39; Marx, "Zur Kritik der politischen Ökonomie" 9). Og alt imens han kunne udpege 'illusioner' ved at udpege kontraster til samfundsforholdenes 'realitet' eller et fremanalyseret 'væsensindhold' bag 'fremtrædelsesformen', påpegede han også, at menneskenes illusioner, ord og forestillinger indgik som et både skabt og skabende aspekt af denne samfundsmæssige væren. Derfor understregede han også, at den ideologikritiske analyse ikke kunne nøjes med at afsløre eller forkaste overbygningsfænomener som tomme for dernæst at pege hen mod et egentligt indhold 'bag' fænomenerne, en art sociale kendsgerninger eller abstrakte strukturer. Tværtimod måtte man forklare de ideologiske former og "tågebilleder" ud fra "de til enhver tid herskende virkelige livsforhold" og som "nødvendige sublimater i deres [dvs. menneskenes] livsproces" (Marx, "Kapital" 393; Marx og Engels, "Die deutsche" I6, min kursivering).

Den nødvendighed, som her blev udpeget i de ideologiske produkter, var ikke en rent objektiv nødvendighed eller absolut historisk uundgåelighed, men en praktisk nødvendighed: nødvendigheden af at gøre A med henblik på at frembringe (eller forhindre) B (jf. Fleischer I28-I52). Selv de mest forvrængede forestillinger var ikke alene historiske frembringelser, de var ofte også historiefrembringende. I Kapitalen understregede Marx, hvorledes menneskenes forestilling om varen rakte hinsides produktets konkret-sanselige brugsværdi (Marx, "Kapital” 85). Religion var tilsvarende ikke blot "folkets opium", der sløvede sansen for denne verdens anliggender, men også "på én gang udtryk for og protest mod den virkelige elendighed" (Marx, "Hegelschen Rechtsphilosophie" 378). Samtidig karakteriserede han også religioner i flertal som historisk bestemte former og illusioner, der på særlig vis betingede menneskenes historiske handlinger og produkter - som f.eks. puritanismens og calvinismens særlige forudsætninger for at fremme den moderne "pengekult" eller lutheranismen, der bidrog til at udforme den moderne borgerlige subjektivitets 
indre modsætninger, idet den "befriede legemet fra lænker ved at lægge hjertet i lænker", eller kætterske sekters kampe mod vidt forskellige former for undertrykkelse (Marx, Grundrisse I43 \& I80; Marx, "Hegelschen Staatsrechts" 386; jf. også Marx, "Kapital" 93).

I denne betragtning af menneskenes ideer og sprog som historisk nødvendige formgivninger af menneskenes livsbetingelser med egne praktiske konsekvenser for den videre reproduktion af det herskende samfundssystems ideologiske betingelser kan vi også finde et grundlag for Marx' tvetydige forhold til det utopiske. Han afviste de udfoldede utopiske forestillinger på grund af deres effekter på den aktuelle frigørelseskamp, på grund af deres tendens til at kræve nutidskampenes underkastelse under bestemte visioner, der var ideologiske ved at forestille sig at repræsentere den frie, ubundne tanke, mens de uundgåeligt var betingede af deres egen historiske ophavssituation. Men han forfægtede samtidig nødvendigheden af at påpege nutidens afgørende mangler fra et imaginært punkt hinsides her og nu en bestemmelse af en mulig bedre tilstand. Dette punkt udgjorde dels et ståsted for samtidskritikken, dels et foreløbigt defineret orienteringsmål for menneskenes frigørelsesbestræbelser.

Det væsentligste punkt af denne art var for Marx den kommunistiske fremtid, der var kendetegnet ved at ophæve netop den aktuelle nutids karakteristiske onder: kapitalens herredømme, klasseskellene, den historisk betingede fremmedgørelse. Samtidig stod denne kommunisme som en fundamental mulighed under det aktuelle samfundssystem, fordi disse onder bestandigt affødte deres negation som immanent effekt af selve systemet, dvs. kampe mod kapitalen, den herskende klasse og fremmedgørelsen (Ollman, Alienation 92-94, II6-II8, I3I-I35, I5O). Dermed var Marx' begreb om kommunismen mønstereksemplet på det, Ernst Bloch betegnede som en konkret utopi, altså en forestilling om et muligt alternativ, der var historisk medieret - forankret i det, Bloch kaldte for tendens og det objektivt-realt mulige, dvs. det, der endnu knap kunne anes, men holdt fremtiden åben. Bloch bestemte dette i modsætning til abstrakte utopier, dvs. fastfrosne arkitekttegningsutopier uden nogen mediering med det allerede eksisterende (Bloch, Tübinger I28-32; Bloch, Prinzip, s. 27I-278, 555-559, 723-729). Kommunismen som det imaginære punkt hinsides det bestående system, der åbnede for kritik af dette system, var - for igen at låne Blochs udtryk - et endnu-ikke, der dog lå i det aktuelt bestående som dets immanente negation: "utopien som ufærdighedens realtilstand" (Bloch, Prinzip 360).

Men Marx' kritik af det bestående forbandt sig også med et ikke-longere, dvs. af erfaringer, erindringer og genkendelser af aspekter af fortiden, hvori nutidens centrale onder endnu ikke havde sat sig igennem, eller hvor tidligere generationer kæmpede for fremtidsfordringer, der lå hinsides den aktuelle nutids fakticitet. Herbert Marcuse udfoldede senere, hvorledes erindringen (anamnesis) hos både individ og art om lystprincippets udfoldelse før civilisationsprincippets repressive funktioner kunne undergrave lydigheden mod det herskende system, danne afsæt for protest: "[F]ortiden bliver ved med at gøre krav på fremtiden, den skaber det ønske, at paradiset må blive genskabt på grundlag af civilisationens resultater. ... La 
recherche du temps perdu bliver et middel til fremtidig frigørelse" (Marcuse, Eros 34f; jf. også Marcuse, Kontrarevolution 85f). Ernst Bloch fremhævede ligeledes, hvordan der kunne findes "fremtid i fortiden", herunder "forhindret fremtid" - de fremtidsrettede muligheder og fordringer, der endnu ikke var realiseret (Bloch "Anticiperet"; Bloch, Erbschaft IIg). Han lagde imidlertid vægt på det fortidiges genvækkelse som noget radikalt nyt og fremadstræbende - ikke anamnesis, men anagnorisis: genkendelsen af det fortidige i nutiden som noget chokerende anderledes, der kunne understrege nutidens fremmedhed fra sig selv (Landmann I78f). Mere poetisk udtrykte Walter Benjamin noget lignende: "Som blomsterne vender deres kroner mod solen, således stræber også alt det forgangne ... efter at vende sig mod den sol, der er ved at stå op på historiens himmel” (Benjamin I6I). Fortidens fremtidsskabelse er her allerede i gang: Fortid og fremtid fremstår for os som historieskabende væsener i vores nutid som åben, processuel relation, hvori vi må forbinde os med fortidens fortrængte stemmer for at vinde den fremtid, der indtil nu er blevet forhindret.

Marcuse, Bloch og Benjamin accentuerer forholdet mellem fortid, nutid og fremtid forskelligt, men kredser om det samme grundproblem. Det samme hovedanliggende gør sig gældende hos Marx. I hans skrifter finder man ganske vist ikke sådanne tanker i form af systematiske historiefilosofiske udredninger, men først og fremmest i formuleringer, der knytter sig til aktuelle handlingsperspektiver og erkendelsesinteresser. Det gælder f.eks. Brumaire-tekstens fremstilling af effekterne af de moderne revolutionæres anakronistiske illusioner. Det borgerlige samfunds "gladiatorer fandt i de klassisk strenge overleveringer fra den romerske republik de idealer og kunstformer, de illusioner, som de trængte til, for at skjule det borgerligt begrænsede indhold i deres kampe for sig selv og holde deres lidenskab på højde med den store historiske tragedie". Den historiske genkaldelse i de borgerlige revolutioner tjente dermed til "i fantasien at overdrive den virkelige opgave" - at "genfinde revolutionsånden" (Marx, "Brumaire" II6). Her var "en med nutid ladet fortid"; "et billede af fortiden, sådan som det uventet indfinder sig for det historiske subjekt i farens stund" (Benjamin I68). De oldromerske roller var altså praktisk nødvendige for, at de moderne borgerlige revolutionære kunne kæmpe heltemodigt for et nyt borgerligt samfund, der reelt ikke bare afskaffede undertrykkelsen, men også erstattede gamle undertrykkelsesformer (monarkiske, aristokratiske) med nye (kapitalistiske). Fortidsillusionernes direkte reference til den samtidige, virkelige praksis, deres funktion som "både dublet og matrice for den virkelige og objektive handling” (Sartre 43), rummede her også utopiske funktioner: De styrkede evnen til at tænke, tale og handle for noget nyt imod det bestående system - så langt som borgerskabet ville og kunne gå.

\section{Strategi og historie}

Marx' anerkendelse af fortidsillusionernes nødvendighed for de frigørende, fremtidsskabende handlinger imod samtidens undertrykkelse gjaldt udtrykkeligt den franske 1789-revolution og den engelske I640-revolution. Men i I848 havde bor- 
gerskabet udspillet den historieskabende, progressive rolle, som Marx her - på et halvt århundredes afstand og som skarp kontrast til sin samtids vankelmodige borgerskab - var villig til at tilskrive den nu praktisk talt uddøde generation af franske revolutionære fra 1789 . I I848 rakte de historiske illusioner derfor kun til en flygtig fortidsrus.

Kontrasten mellem borgerskabet i disse to perioder knytter sig ikke bare til makrohistoriske antagelser om denne klasses transformation fra progressiv til regressiv kraft. Først og fremmest udtrykker den både specifikke performative, politisk-strategiske aspekter og en mere almen kritik af tingsliggørende relateringer af fortid og nutid. Jeg vil begynde med det første.

Marx' skarpe afstandtagen til borgerskabets tingsliggjorte og tingsliggørende fortidsbetragtning i 1848 hang sammen med nyindhøstede politiske erfaringer med borgerskabet $i$ den selv samme historiske situation. Nok havde Marx allerede i 1844 udpeget proletariatets sociale revolution som krumtappen i den moderne emancipation: "Det er ikke den radikale revolution, ikke den almenmenneskelige frigørelse, der er en utopisk drøm for Tysklands vedkommende, men tværtimod den delvise, den kun politiske revolution - den revolution, der lader husets grundpiller blive stående" (Marx, "Hegelschen Rechtsphilosophie" 388). Men den politiske revolution - skabelsen af en moderne stat i relation til frie borgere efter den første franske revolutions forbillede - havde samtidig fungeret som verdenshistorisk forudsætning for den radikale, almenmenneskelige revolution. Og i årene op mod I848 havde Marx og Engels i højere grad betragtet fuldbyrdelsen af en distinkt borgerlig revolution som en nødvendig politisk og historisk mediering af dette mere vidtrækkende perspektiv. Arbejderne måtte "medtage den borgerlige revolution som en betingelse for arbejderrevolutionen", også selv om de aldrig skulle betragte den som deres "endemål", skrev Marx i efteråret I847 (Marx, "Die moralisierende" 352). Selv den kraftfulde kundgørelse af proletariatet som historieskabende subjekt i Det kommunistiske partis manifest få måneder senere udpegede et lignende faseskel mellem en umiddelbart forestående tysk borgerlig revolution og en efterfølgende proletarisk verdensrevolution (Marx og Engels, "Manifest" 492f). I løbet af revolutionsåret I848 søgte Marx og Engels følgelig at alliere sig med kræfter på borgerskabets demokratiske venstrefløj, ikke mindst ved udgivelsen af dagbladet Neue Rheinische Zeitung fra juli I848 og frem.

Denne strategiske satsning på et distinkt borgerligt-revolutionært stadie i samtiden blev $\mathrm{i}$ et vist omfang støttet af historiske forbilleder. Især den første franske revolution fra $\mathrm{I} 789 \mathrm{og}$ frem, men også tidligere revolutionære brud som i England I640-60, blev fremhævet som polemiske Verfremdungsskildringer af borgerskabets heroiske fortid som anderledes heroisk end dets nutid. Derigennem kunne Marx søge at øve et pres på denne klasse - anspore den til at overvinde sin aktuelle vankelmodighed. I december I 848 skrev han således i en kritisk status over sin samtids tyske borgerskab, at begge disse tidligere revolutioner havde været kendetegnet ved borgerskabets resolutte handling som den klasse, der "virkelig befandt sig i spidsen for bevægelsen" og derved sikrede "en ny samfundsordens sejr", ikke bare 
for Frankrig og England, men på europæisk plan (Marx, "Die Bourgeoisie" I07). Borgerskabet havde også været bevidst om denne almene rolle som befrier, hævdede han i en artikel få måneder tidligere. I modsætning til det nutidige tyske borgerskab havde det franske i 1789 ikke svigtet sine forbundsfæller, bønderne: "De vidste, at grundlaget for deres [dvs. borgerskabets] herredømme var sønderknusningen af feudalismen på landet, skabelsen af den frie, grundbesiddende bondeklasse" (Marx, “Die Gesetzentwurf” 283).

De skarpe modsætninger mellem arbejderne og de nye, ofte erklæret 'demokratiske', borgerligt anforte regimer i I848 - ikke mindst under de blodige konfrontationer i 'junidagene' i Paris - gjorde det imidlertid vanskeligt at fastholde klassealliancen. Dette førte efterhånden til en ny strategisk orientering i sammenhæng med nye karakteristikker af de kæmpende klasser. I stigende grad udpegede Marx og Engels proletariatet som selvstændigt handlende klassesubjekt i en revolution, der måtte være permanent, dvs. i én uafbrudt bevægelse føre fra den borgerlige revolutions opgør med feudale, præborgerlige levn videre til proletariatets kamp for hegemoni (Jf. f.eks. Marx, "Die Klassenkämpfe" 89f; Draper; Hunt). Derfor understregede Marx også i Brumaire-teksten, at navnlig den erklæret demokratiske venstrefløj, småborgerskabet og bønderne havde lidt nederlag over for bourgeoisiet og den stærke stat, fordi de ikke havde hentet deres "krafttilskud fra proletariatet". De burde have støttet proletariatets kampe i junidagene og senere. I stedet havde de "smittet det med [deres] egen svaghed". Proletariatet burde have været en "erobrende magt" (Marx, "Brumaire” I43 \& I57). Og nu, efter juninederlaget, måtte det atter rejse sig for at blive netop sådan en magt. Dette proletariat som den fremtidsskabende kraft var således allerede nutid, men en nutid i sin vorden. Denne bestemmelse af nutiden synes nært beslægtet med Ernst Blochs bestemmelser af nuet som tomt, mørkt, usamtidigt, endnu ikke udfyldt og dog nogle gange mere mættet end ellers (jf. f.eks. Bloch, Hoffnung 356; Bloch, Tübinger I2 \& I90; Bloch, Erbschaft Io4ff). Marx' politiske polemik søgte at bidrage til denne vorden og en bestemt udfyldning af dette $n u$ ved ikke bare at konstatere, men snarere fremmane proletariatet som en bevidst, historieskabende, kæmpende klasse for sig selv (jf. Marx, "Misère" 226).

Også denne strategiske reorientering udviklede han i tæt dialog med elementer af fortiden. Vægten lå på andre aspekter af den revolutionære fortid end lige netop dens borgerlige hegemoni eller borgerskabets handlekraft. Som Michael Löwy har understreget, findes der betydelige indre divergenser i Marx' og Engels' forskellige udsagn om jakobinismen og de folkelige bevægelser i den første franske revolution (Löwy II5-20, jf. også Schmitt og Meyn; Avineri I85-20I; Furet; Nygaard). De jakobinske førere kunne det ene øjeblik omtales som "virkelige repræsentanter" for masserne og som de sande forløbere for "nutidens kommunister", det næste øjeblik som repræsentanter for "den energiske bourgeoisiliberalisme", der til trods for sine almuevenlige erklæringer lod alle love bestå, som var rettet mod arbejdere (Marx og Engels, "Die deutsche” I60 og I77; Marx, "Gedenkfeier" 5I9; Marx, "Kapital” 769f). Nogle gange fokuserede Marx og Engels således på jakobinismen, andre gange på 
de lavere klassers selvstændige handling uden om eller imod jakobinerne.

Fælles for disse karakteristikker var imidlertid, at de søgte efter elementer i fortiden, som rummede mere end et blot ophav til den nutid, som borgerskabet ville monopolisere. Tilsvarende fremhævede Marx i Brumaire, hvorledes den første franske revolution havde været kendetegnet ved det stadigt mere radikale og "dristige" partis sejr over sine moderate forgængere. I denne revolutionære fortid kunne man således se en stadig bevægelse videre - i modsætning til I848-revolutionerne, der standsede ved (eller rettere: før) den forgangne borgerlige revolutions grænser (Marx, "Brumaire" 135).

Samtidig fremhævede Marx og Engels i stigende grad proletariatet som signifikant modsætning til borgerskabet også i de tidligere borgerlige revolutioner. Marx bemærkede således i 1848: "Hele den franske terrorisme var intet andet end et opgør med bourgeoisiets fjender på plebejisk maner" (Marx, "Die Bourgeoisie" 107). De lavere klassers handlinger havde også i den første franske revolution været nødvendige for den borgerlige revolutions gennemførelse - ja, endda for borgerskabets revolutionære aspirationer overhovedet. Overladt til sig selv havde borgerskabet nemlig heller ikke været revolutionært i I789: "Det ængsteligt-hensynsfulde bourgeoisi havde ikke kunnet gøre dette arbejde færdigt på årtier. Folkets blodige aktion beredte det vejen" (Marx, "Die moralisierende" 306). Den revolutionære kraft havde været "den 'talløse' masse" - og altså ikke selv de mest radikale blandt de kendte ledere (Marx og Engels, "Die deutsche" I60).

Dermed blev det klarere, hvad der siden midten af I840'erne havde været det gennemgående tema i både Marx' og Engels' beskæftigelse med fortiden: De lavere klassers revolutionære historie midt i de borgerlige revolutioners epoke var ikke blot tilbagelagte, døde kendsgerninger eller rene redskaber til borgerskabets sikring af en bestemt epokes forudbestemte fremskridt. For Marx og Engels fungerede de udtrykkeligt som støtte- og identifikationspunkter for den proletariske befrielseskamp, der skulle etableres her og nu - ganske som "erindringen om juni I848" for Marx i et snævrere historisk perspektiv kunne forklare proletariatets stadige modstandskamp mod repressionen i de følgende måneder og år (Marx og Engels, "Manifest" 489; Marx, "Brumaire" I44). De repræsenterede også den forhindrede fremtid i fortiden, der stod som fordring i og til nutiden.

\section{Mod fortidens tingsliggørelse}

Den nævnte kontrast mellem Marx' karakteristikker af I789 og I848 rummede mere almene teoretiske implikationer. Her var ikke blot tale om et skel mellem hermeneutisk fortidsforståelse og polemisk samtidskritik. Det var også et skel mellem to typer af interaktion mellem fortid og nutid. Han forkastede den abstrakttingsliggørende betragtning af fortiden som en diktatorisk anden, der påbyder lydighed mod den hypostaserede udvikling eller det historiske forbillede som en model til identisk gentagelse. Derimod fordrede han en anden type fortidsbrug: den praktisk-skabende, bevidst nutidsbundne genkaldelse af frihedsmomenter og 
historieskabende handling i fortiden. Han fordrede med andre ord en forbindelse mellem fortidens og nutidens historieskabelse som - med Georg Lukács' udtryk "momenter af én og samme realhistoriske, dialektiske proces" (Lukács 395).

Man kan ane kritikken af fortidens tingsliggørelse i Marx' kritik af især borgerskabets brug af historien i i848. For de borgerlige revolutionære var revolutionen ikke længere noget, der skulle skabes og udkæmpes som noget radikalt nyt. Den syntes som et færdigskrevet manuskript, overleveret fra den store franske revolution et halvt århundrede før. Den måtte for borgerskabet ikke rumme mere end det, der lå i den model af 1789 , som borgerlig-liberale historietolkere havde formet gennem årtier (Mellon; Neumüller). Her var kun de elementer af fortiden, der kunne udpeges som ophav til det borgerlige samfunds egen epoke, dets egen hegemoniserede nutid - i dette tilfælde kendetegnet ved den 'klassiske' borgerlige offentligheds normative orden, som legitimerede borgerskabets herredømme ved henvisninger til den form for 'fornuft', som de lavere klasser (og kvinderne) var strukturelt afskåret fra (Habermas). I dette ideologiske univers var den rette, legitime revolution en sluttet, tingsliggjort helhed - et fatum, bestemt af I789-fortiden som en abstrakt anden.

Denne kritik gjaldt et alment træk ved de borgerlige historieforståelser, der blev fremherskende op gennem det lange I9. århundrede: Betragtningen af fortiden som "døde kendsgerninger" og kendetegnet ved hver enkelt epokes herskende "illusion" om sig - illusioner, der reelt var"den herskende klasses tanker" - var netop tingsliggørende: De herskende klassers hegemoniske fremstillinger omskrev de historiske frembringelser til et "tingsligt særpræg ved produkterne selv"; de løsrev altså disse frembringelser fra de historiske processer og handlinger, der havde frembragt dem (Marx og Engels, "Die deutsche" I6, 28 og 35; Marx, "Kapital" 86).

Denne tingsliggørelse af fortiden som en fremmed anden, uden forbindelse til praksis i nutid eller fortid, udgjorde forudsætningen for den ligeledes karakteristisk borgerlige opfattelse, at historien var afsluttet med realiseringen af det moderne borgerlige samfund - en tanke, vores egen tid bedst kender i Fukuyamas slagordsfremstilling. Marx bemærkede, at der for de borgerlige skribenter "har eksisteret historie", fordi verden engang ikke så ud som nu, men at historien "ikke eksisterer mere", fordi verden nu endelig har realiseret det samfund, der ifølge det borgerlige samfunds apologeter svarer til menneskets 'natur' (Marx, "Misère" I88). Marx kritiserede her en karakteristisk opfattelse af nutiden som "formål" for den tidligere historie - og tilsvarende af fortiden som udelukkende ophav til én hegemoniseret nutid. Dette var blot "en abstraktion af den aktive indflydelse, som den tidligere historie udøver på den senere" - altså et udslag af tingsliggørelse (Marx og Engels, "Die deutsche" 35).

Det var dermed ikke fortidsbevidstheden som sådan, der var skyld i den borgerlige nutids handlingslammelse. Tværtimod lå problemet $i$, at den tingsliggørende historiebetragtning ikke virkelig genkaldte sig eller erkendte fortiden som proces, handling og tilblivelse, men kun dens abstrakte model- eller ophavskarakter. Heri lå en glemselsproces svarende til det, Marx kritiserede som "den parlamentariske 
kretinisme", dvs. parlamentspolitikernes fastfrysning i en "indbildt verden", der frarøvede dem "ethvert begreb, enhver erindring, enhver forståelse af den hårde verden udenfor", dvs. de sociale kampes verden (Marx, "Brumaire" 173, min fremhævelse). Marx pegede her i specifik form på et forhold, Adorno og Horkheimer senere satte på almen formel: "Enhver tingsliggørelse er en glemsel" (Horkheimer og Adorno 244). Det, de borgerlige I848-revolutionæres fortidsabstraktioner fortrængte, var selve den revolutionære historiske åbenhed, dens skabelse og udformning gennem konkrete kampe, herunder de historiske sprog og bevidsthedsformer, der måtte være nødvendige for at gennemføre sådanne afgørende handlinger. Netop fordi borgerskabet ville betragte historien som - med de allerede citerede ord fra Marx - "døde kendsgerninger", kunne de "døde" herske over de "levende", fortidens virkelige helte gå igen som spøgelser.

Denne borgerlige tilgang til historien som sammensat af døde kendsgerninger og i deres egenskab af døde kendsgerninger rent abstrakte, formelt identiske - om fortiden er beslægtet med to indbyrdes sammenhængende, tingsliggørende opfattelser af tid overhovedet: Den første er opfattelsen af historisk tid som et stadialt fremskridt hen mod realisering af den generaliserede vareproduktion og dens individualisme som kernen i menneskets natur, der anses for teleologisk indskrevet i mennesket allerede ved dets artsoprindelse - altså den historiske tid, der lige siden I70o-tallets civilisationshistorie hos f.eks. Adam Smith og Turgot er blevet fremstillet med det kapitalistiske samfund som kulminations- og afslutningspunkt.

Den anden tidsopfattelse, som svarer til dette borgerlige samfunds atomisering og kvantificering af menneskelige forhold, er den kvantificerede tid med dens slette uendelighed af formelt ensartede enheder: urets og kalenderens tid - med Henri Lefebvres ord den moderne lineare tid, der er kontinuerlig, idet "den begynder absolut, den vokser i uendelighed fra et initialt nulpunkt", men samtidig diskontinuerlig, fragmenteret i en abstrakt flerhed af tider (Lefebvre 53). Marx bemærkede, hvordan denne form for tid begyndte at fungere som en abstrakt magt over menneskene med den masseindustrielle kapitalisme og lønarbejdets generalisering: "Tiden er alt, mennesket er intet længere, det er allerhøjst legemliggørelse af tiden. Det drejer sig ikke længere om kvalitet. Kvantiteten alene afgør alt; time mod time, dag mod dag" (Marx, "Misère" I38, jf. også f.eks. Marx, "Kapital" 299). Den afmagt, der bliver tilbage hos menneskene, som lever under denne tid, gjorde sig ifølge Marx også gældende i den anden franske republiks historie fra I848 og frem: Her var "helte uden heltegerninger, historie uden begivenheder; en udvikling, hvis eneste drivkraft synes at være kalenderen, trættende ved en stadig gentagelse af den samme spænding og den samme udløsning" (Marx, "Brumaire" I36). Den moderne tingsliggørelse af disse tidskategorier som abstrakte magter over mennesket fører således til, at man glemmer, hvorledes disse kategorier selv er historisk frembragte og til stadighed konstitueres som ideologiske magter gennem deres udøvelse i dagligdagen (jf. Althusser; Žižek). 


\section{Historien som praksistotalitet}

I modsætning til den tingsliggjorte betragtning af historien og tiden fordrede Marx en historie med begivenheder og heltegerninger. Han ville med andre ord anerkende historien som noget, der til stadighed var under skabelse og omskabelse ved menneskers indbyrdes samfundsmæssige handlinger. Dette var for ham ikke blot en moralsk fordring om handling, men også en grundbetragtning af den historie, som faktisk fandt sted. De berømte passager, der kan ligne skematisk-teleologiske opregninger af universalhistoriske udviklingsstadier fra antikken over feudalismen til kapitalismen, var sigende korte og formuleret med udtrykkelige forbehold: kun i "store omrids", kun de "progressive epoker i den økonomiske samfundsformation", kun gældende for "landene i Vesteuropa" (Marx, "Zur Kritik der politischen Ökonomie" 9; Marx, "Entwürfe einer Antwort" 384). Og selv denne gyldighedsafgrænsning afhang af perspektivet og erkendelsesinteressen. For det gjaldt overalt om at "udforske menneskenes virkelige profane historie $i$ hvert årbundrede, at skildre disse mennesker, sådan som de på én og samme tid var forfattere til og medvirkende i deres eget drama (les auteurs et les acteurs de leur propre drame)" (Marx, "Misère" I84, min fremhævelse). Menneskene var således ikke bare statister i 'Historien', men udformede selv (bevidst eller ubevidst) deres historie gennem deres handlinger.

Dette alternativ til historiens tingsliggørelse betyder langtfra en fuldstændig overvindelse af den relative afstand mellem nutid og fortid eller nogen bestræbelse på at etablere en absolut, guddommelig identitet mellem erkendelsens subjekt og dens objekt. Tværtimod er den relativerende betragtning af objektet som historisk produkt en forudsætning for en frugtbar udnyttelse af den relative afstand mellem fortiden som objekt og det nutidige erkendende subjekt ved en kontrapunktisk historisk erkendelsesproces, der aktivt og bevidst gør objektet til et objekt for subjektets erkendelse og handling.

Her finder vi således en betragtning af historien som en multilineær, konfliktuel, hyppigt afbrudt, atter påbegyndt og igangværende proces af historieskabende handlinger. Få linjer efter sin afvisning af 'fortidens poesi' i Brumaire understregede Marx, at det 19. århundredes proletariske revolutioner også vender tilbage til det forgangne, men på deres egen måde, der gør fortiden til fortid for den kæmpende, fremtidsrettede nutid. Disse revolutioner

"kritiserer bestandig sig selv, afbryder stadig deres eget forløb, kommer tilbage til det, som tilsyneladende er fuldført, for at tage fat på det igen, de forhåner grusomt og grundigt halvhederne, svaghederne og ynkelighederne i deres første forsøg". (Marx, "Brumaire" II8)

I stedet for den borgerlige historieforståelses projektion af borgerskabets aktuelle hegemonifordring som en absolut anden, der dikterer sine færdige modeller over for en nutid uden andre muligheder, vil Marx fremgrave samklange - harmoniske eller disharmoniske - mellem de historieskabende kampe i fortid og nutid som 
grundingredienser i selve den aktuelle politiske handling. Ud fra sådanne grundbetragtninger - og ved første øjekast i diametral modsætning til Marx’ kritik af fortidsdyrkelsen i Brumaire - kunne Marx og Engels allerede i I845 anfægte de stadigt tilbagevendende forsøg på at erklære den franske revolution for død og begravet fortid: "Den franske revolutions livshistorie, der daterer sig fra I789, er endnu ikke afsluttet med året I830”, dvs. med julirevolutionens omstyrtelse af det genoprettede monarki (Marx og Engels, "Die heilige" I3I). For borgerskabet i 1848 måtte den gamle franske revolution netop forekomme som et afsluttet ophav til eller mønster for det borgerlige samfunds nutid. For Marx og Engels rummede den derimod et overskud: hidtil uindløste løfter om fremtidig emancipation - forhindret fremtid.

Som alternativ til ikke kun de tingsliggjorte tidsopfattelser, der legitimerede og opretholdt det borgerlige samfund, men delvis også til de mere kritiske hermeneutiske tilgange til tid som historisk relativ fortolkning, kan man her ane Marx' særlige betragtning af tiden som et produkt af menneskenes sociale forhold, et produkt under bestandig social op- og ombygning og dermed altid genstand for kampe $i$ et modsætningsfyldt, dynamisk nu. Det var fra dette standpunkt, han afviste ikke kun det tingsliggørende fortidsbrug, men også utopisternes abstrakte fremtidsbilleder.

\section{Konklusion}

Marx forkastede således nok fortidens hjemsøgelse af nutiden. Men det var ikke enhver fortidsfascination, han anså for reaktionær - kun betragtninger af historien som en ting, et lukket, afsluttet objekt. De karakteristiske borgerlige, tingsliggørende betragtninger af fortiden som enten ophav til nutiden eller som en serie modeller til simpel gentagelse var illusoriske, men uvægerligt nutidsbestemte ideologiske fantasier, der fungerede som cement i borgerskabets hegemoniske magtudøvelse. Disse betragtninger var for Marx ikke kritisable ved deres brug af fortiden som sådan, men paradoksalt nok ved deres konstruktion af fortiden som en illusorisk, abstrakt anden.

Derfor var hans budskab heller ikke, at den moderne revolutionære befrielse fra det borgerlige samfunds undertrykkelsesrelationer skulle foregå løsrevet fra fortiden, men tværtimod at fortiden kunne restitueres som fortid ved at sættes $i$ et praksisforhold til nutiden. Proletariatets aktuelle emancipationskamp stod dermed ikke i modsætning til historisk erkendelse, men var et bidrag til en aftingsliggjort erkendelse af fortiden som en historie, der til stadighed var skabt og omskabt gennem menneskelige handlinger. Proletariatet skulle ikke genskabe I789 eller I848 som modeller, men gøre sig til forfattere i deres egen historieskabelse, dvs. skabe deres egen revolution, ligesom de tidligere revolutionære havde gjort i deres historiske situationer.

Gennem Marx' tilgang til fortidens utopiske potentialer kan man således finde en praktisk udfoldelse af en tilgang, der fjerner sig fra både den erklæret 'realistiske' eller 'pragmatiske' antiutopisme og utopismens eskapistiske drømmeri med deres 
fælles rodfæstelse i selvbedrageriske antagelser om ideologifri erkendelseszoner (henholdsvis i eller imod den eksisterende virkelighed). I stedet fordrer Marx en forankring af de utopiske drømmeriers bevidst nutidige kamphandlinger, der ikke desto mindre uvægerligt forbinder sig med potentialer i det forgangnes og det tilkommende som mulige aspekter i og for dette $n u$.

\section{LITTERATURLISTE}

Abensour, Miguel. "L'Histoire de l'utopie et le destin de sa critique”. Textures 6/7 (I973): 3-26; 8/9

(1974): 55-8I.

Althusser, Louis. Ideologi og ideologiske statsapparater. Aalborg: Grus, 1983 [1969].

Anderson, Perry. Considerations on Western Marxism. London: New Left Books, 1976.

Avineri, Shlomo. The Social and Political Thought of Karl Marx. Cambridge: Cambridge University Press, I968.

Benjamin, Walter. "Om historiebegrebet”. Kulturkritiske essays. København: Gyldendal, I998.

Bensaïd, Daniel. Marx for Our Times: Adventures and Misadventures of a Critique. London \& New York:

Verso, 2002.

Bloch, Ernst. “Anticiperet realitet - hvad er utopisk tænkning, og hvad kan den?”.

Bloch, Ernst. Das Prinzip Hoffnung. Frankfurt am Main: Suhrkamp, 1959.

Bloch, Ernst. Erbschaft dieser Zeit. Frankfurt am Main: Suhrkamp, I962 [I935].

Bloch, Ernst. Tübinger Einleitung in die Philosophie. Bd. I. Frankfurt a.M.: Suhrkamp, 1963.

Ernst Bloch - en introduktion. Red. Jørn Erslev Andersen m.fl. Århus: Modtryk, I982.

Draper, Hal. The Politics of Social Classes: Karl Marx' Theory of Revolution. Volume 2. New York: Monthly Review Press, I977.

Engels, Friedrich. "Vorrede zur dritten Auflage [(I885) 'Der achtzehnte Brumaire des Louis Bonaparte’ von Karl Marx]”. MEW 2I. s. 248-249.

Fleischer, Helmut. Marxismus und Geschichte. Frankfurt am Main: Suhrkamp, 1969.

Furet, François. Marx et la Révolution française. Paris: Flammarion, 1986.

Geoghegan, Vincent. Utopianism and Marxism. Oxford \& Bern: Peter Lang, 2008.

Habermas, Jürgen. Borgerlig offentlighed. Offentlighedens strukturandring, Undersogelser af en kategori i det borgerlige samfund. København: Informations forlag, 2009.

Hobsbawm, Eric. How to Change the World: Marx and Marxism I840-20II. London: Little, Brown, $20 I I$.

Horkheimer, Max og Theodor W. Adorno. Dialektik der Aufklärung. Frankfurt a.M: Fischer, I998 [I944].

Hunt, Richard. The Political Ideas of Marx and Engels: Volume I: Marxism and Totalitarian Democracy I8I8-1850. London \& Basingstoke: Macmillan, I975.

Jameson, Fredric. Archaeologies of the Future: The Desire Called Utopia and Other Science Fictions. London: Verso, 2005 .

Landmann, Michael. "Talking with Ernst Bloch: Korčula, I968”. Telos 25 (I975): I65-I85.

Lefebvre, Henri. Critique de la vie quotidienne. II. Fondements d'une sociologie de la quotidienne. Paris:

L'Arche Éditeur, 196I. 
Levitas, Ruth. The Concept of Utopia. Syracuse: Syracuse University Press, I990.

Lukács, Georg. Geschichte und Klassenbewußtsein. Neuwied \& Berlin: Luchterhand, 1968 (Georg Lukács Werke, bd. 2).

Löwy, Michael. “The Poetry of the Past'. Marx and the French Revolution”. On Changing the World: Essays in Political Philosophy from Karl Marx to Walter Benjamin. Atlantic Highlands: Humanities Press, I993.

Maler, Henri. Convoiter l'impossible. L'utopie avec Marx, malgré Marx. Paris: Albin Michel, I995.

Marcuse, Herbert. Eros og civilisationen. København: Gyldendal, I970.

Marcuse, Herbert. Kontrarevolution og venstrefløj. København: Gyldendal, I974.

Marin, Louis. Utopiques. Jeux d'espaces. Paris: Les éditions de minuit, I973.

Martin, James. "Performing Politics: Class, Ideology and Discourse in Marx's Eighteenth Brumaire". Marx's Eighteenth Brumaire: (Post)Modern Interpretations. Red. Mark Cowling og James Martin.

Oxford: Pluto Press, 2002. I29-I42.

Marx, Karl. "Kritik des Hegelschen Staatsrechts” (I843). MEW I. 203-233.

Marx, Karl. "Zur Kritik der Hegelschen Rechtsphilosophie. Einleitung” (I843-I844). MEW I. 378-39I.

Marx, Karl. "Misère de la philosophie" (I846). MEGA, I:6.

Marx, Karl. "Die moralisierende Kritik und die kritisierende Moral” (I847). MEW 4. 33I-359.

Marx, Karl. "Die Bourgeoisie und die Kontrerevolution” (I848). MEW 6. IO2-I24.

Marx, Karl. "Die Gesetzentwurf über die Aufhebung der Feudallasten" (I848). MEW 5. 278-283.

Marx, Karl. "[Reden auf der Gedenkfeier in Brüssel. Rede von Marx]” (I848). MEW 4. 5I9-522.

Marx, Karl. "Die Klassenkämpfe in Frankreich I848-50” (I850). MEW 7. 9-IO7.

Marx, Karl. "Der achtzehnte Brumaire des Louis Bonaparte” (I852). MEW 8. III-207

Marx, Karl. Grundrisse der Kritik der politischen Ökonomie (Rohentwurf) (I857-58). Berlin: Dietz, I974.

Marx, Karl. "Zur Kritik der politischen Ökonomie. Vorwort” (I859). MEW I3. 7-II.

Marx, Karl. "Provisorische Statuen der Internationalen Arbeiter-Assoziation” (I864). MEW I6. I4-I6.

Marx, Karl. "Das Kapital I” (I867). MEW 23.

Marx, Karl. "Vorwort [zur Zweiten Ausgabe (I869) 'Der achtzehnte Brumaire des Louis Bonaparte']”. $M E W$ I6. 358-360.

Marx, Karl. "Vorwort und Nachwort zur französischen Aufgabe" (I872, I875). MEW 23. 3I-32.

Marx, Karl. "Nachwort zur zweiten Auflage" (I873). MEW 23. I8-28.

Marx, Karl. "[Entwürfe einer Antwort auf den Brief von V.I. Sassulitsch]” (I88I). MEW I9. 384-406.

Marx, Karl og Friedrich Engels. "Die heilige Familie" (I845). MEW 2. 3-223.

Marx, Karl og Friedrich Engels. "Die deutsche Ideologie" (I846). MEGA I:5.

Marx, Karl og Friedrich Engels. "Manifest der kommunistischen Partei” (I848). MEW 4. 459-493.

Marx, Karl og Friedrich Engels. Marx Engels Gesamtausgabe. Berlin/Moskva: Marx-Engels Verlag, 1927-I935 (her forkortet $M E G A+$ serienr. + bindnr.).

Marx, Karl og Friedrich Engels. Marx Engels Werke. Berlin: Dietz I960-9o (her forkortet MEW bindnr.).

Mellon, Stanley. The Political Uses of History: A Study of Historians in the French Restoration. Stanford: Stanford University Press, 1958.

Neumüller, Michael. Liberalismus und Revolution. Das problem der Revolution in der deutschen liberale Geschichtsschreibung des 19. Jahrhunderts. Düsseldorf: Pädagogischer Verlag Schwann, I973.

Nygaard, Bertel. "The Meanings of Bourgeois Revolution”. Science and Society 7I:2 (2007). I46-I72. 
Ollman, Bertell. Alienation: Marx's Conception of Man in Capitalist Society. Cambridge: Cambridge University Press, 1976.

Ollman, Bertell. Dance of the Dialectic: Steps in Marx's Method. Urbana \& Chicago: University of Illinois Press, 2003

Sartre, Jean-Paul. Eksistentialisme og marxisme. København: Gyldendal, 1969.

Schmitt, Eberhard og Matthias Meyn. "Ursprung und Charakter der Französischen Revolution bei Marx und Engels”. Vom Ancien Régime zur französischen Revolution. Red. Ernst Hinrichs. Göttingen: Vandenhoecht \& Ruprecht, I978. 588-649.

Žižek, Slavoj. “The Spectre of Ideology”. Mapping Ideology. Red Slavoj Žižek. London \& New York: Verso, 1994. 